\title{
COMPARISON OF ANTIBACTERIAL EFFICACY BETWEEN XANTHORRHIZOL (CURCUMA XANTHORRHIZA ROXB.) AND CHLORHEXIDINE 2\% AGAINST ENTEROCOCCUS FAECALIS CLINICAL ISOLATE BIOFILM
}

\author{
RIZA PERMITASARI ${ }^{1}$, KAMIZAR NAZAR ${ }^{2 *}$, RATNA MEIDYAWATI ${ }^{2}$, RIZKA EKA PRASETYANTI ${ }^{1}$ \\ ${ }^{1}$ Conservative Dentistry Residency Program, Faculty of Dentistry, Universitas Indonesia, Indonesia. ${ }^{2}$ Department Conservative Dentistry, \\ Faculty of Dentistry, Universitas Indonesia. Indonesia. Email: kamizar_kz@yahoo.com \\ Received: 25 September 2019, Revised and Accepted: 29 June 2020
}

\section{ABSTRACT}

Objective: In root canal treatments, chlorhexidine (CHX) is widely used for irrigation and is effective in killing Enterococcus faecalis. CHX is a synthetic chemical and is toxic to host cells; therefore, natural or herbal irrigation solutions, which are safer but still effective, are necessary. The aim of this study is to analyze the effect of xanthorrhizol (XNT) derived from Curcuma xanthorrhiza Roxb. on E. faecalis clinical isolate biofilm formation (0.5\%, $0.75 \%, 1 \%, 1.25 \%$, and $1.5 \%)$.

Methods: The MTT assay and total plate count were performed for assessing the effectiveness of herbal ingredients, while CHX (2\%) was used as a positive control. Data were analyzed using one-way ANOVA and Bonferroni post-hoc tests for analyzing differences between groups.

Results: Xanthorrhizol concentrations of $0.5 \%, 0.75 \%, 1 \%, 1.25 \%$, and $1.5 \%$ reduced the amount of bacteria that grew as biofilms in vitro. We found that the ability of xanthorrhizol $1 \%$ to inhibit $E$. faecalis biofilm formation was not significantly different compared with that of $\mathrm{CHX} 2 \%$ (p>0.05).

Conclusion: Xanthorrhizol 1\% can inhibit biofilm formation by E. faecalis. Further studies are required to confirm this preliminary result.

Keywords: Xanthorrhizol, Enterococcus faecalis, Chlorhexidine, Antibacterial.

(c) 2020 The Authors. Published by Innovare Academic Sciences Pvt Ltd. This is an open access article under the CC BY license (http://creativecommons. org/licenses/by/4. 0/) DOI: http://dx.doi.org/10.22159/ijap.2020.v12s2.PP-05

\section{INTRODUCTION}

Resistant microorganisms can cause failed root canal treatments. Enterococcus faecalis is the most prevalent resistant bacterium that is found in root canal post-endodontic treatment. According to Siqueira and Rocas [1], E. faecalis is the most prevalent bacterium, as much as $77 \%$, found in failed endodontic treatments [2]. This bacterium can form biofilms in root canals, making it 1000 times more resistant to antimicrobials compared to its planktonic form [3]. Virulence possessed by $E$. faecalis enables biofilm formation in host tissue and resistance to host defense mechanisms [4].

Root canal treatments require irrigation solutions with antibacterial properties. Chlorhexidine ( $\mathrm{CHX}$ ) is widely used for irrigation in endodontic treatment and is effective in killing E. faecalis. According to Ferraz (2007), 2\% CHX in the form of gels and solutions is more effective in eliminating E. faecalis than $5.25 \% \mathrm{NaOCl}$ [5]. CHX is a synthetic chemical, but literatures show that it is toxic to host cells. According to Faria (2009), using CHX for irrigation can result in apoptosis and necrosis of fibroblast cells [6,7]. Therefore, alternative irrigation solutions from natural or herbal ingredients are needed. Herbal ingredients are safer and effective to kill E. faecalis [8].

Curcuma xanthorrhiza Roxb. or temulawak is a herbal ingredient that is effective against E. faecalis [8]. Xanthorrhizol (XNT) is a unique phytochemical compound found in Curcuma xanthorrhiza Roxb. [8]. It has been reported for its antibacterial, antifungal, anticancer, antioxidant, and anti-inflammatory properties [8]. According to Yue et al. (2015), xanthorrhizol 1\%, which is the fractionated form of Curcuma xanthorrhiza Roxb., is more effective against $E$. faecalis ATCC 29212 biofilms than CHX at concentrations of $0.0625 \%$ and $0.03325 \%$ in alkaline conditions [9]. Xanthorrhizol is a non-toxic herbal ingredient with antibacterial properties [10].
At present, to the best of our knowledge, no studies have compared the antibacterial effect of xanthorrhizol fractionated from Curcuma xanthorrhiza Roxb. on clinical isolate E. faecalis biofilm with that of CHX 2\%. Therefore, this study analyzed the antibacterial effect of xanthorrhizol fractionated from temulawak (Curcuma xanthorrhiza Roxb.) at different concentrations $(0.5 \%, 0.75 \%, 1 \%, 1.25 \%$, and $1.5 \%)$ against $E$. faecalis clinical isolate biofilm and compared the same with CHX $2 \%$.

\section{MATERIALS AND METHODS}

Xanthorrhizol used in this study was obtained from PT. Tri Rahardja (Javaplant), Indonesia, isolated from a fraction of the ethanol extract of Javanese Turmeric (Curcuma xanthorrhiza Roxb.). Analysis of xanthorrhizol content was performed using gas chromatographymass spectrometry at Laboratorium Kesehatan Daerah (Labkesda, Indonesia). It showed that xanthorrhizol used in this study had a concentration of $95 \%$. Xanthorrhizol was diluted with dimethyl sulfoxide (DMSO) for obtaining concentrations of $0.5 \%, 0.75 \%, 1 \%$, $1.25 \%$, and $1.5 \%$ using the following formula: C1.V1 $=$ C2.V2. The targeted bacteria for this study were E. faecalis that was isolated from patients with non-vital teeth and periapex abnormalities who required endodontic treatment. Bacterial clinical isolates with ethical numbers: 99/Ethical Approval/FKGUI/X/2014. Bacterial cultures of clinical isolates were grown in CHROMagar, which was chosen because it provides presumptive identification of $E$. faecalis directly from clinical samples. Plates were incubated at $37^{\circ} \mathrm{C}$ for $24 \mathrm{~h}$. They appeared as bluish colonies. E. faecalis that already grew were collected with the use of an ose needle until one full loop, then inoculated into a tube of brain heart infusion (BHI) broth with a suspension of $1 \times 10^{8}$ cells $/ \mathrm{mL}$ (McFarland standard). The tube was centrifuged using a vortex mixer, then incubated anaerobically with $5 \% \mathrm{CO}_{2}$ for $24 \mathrm{~h}$ at $37^{\circ} \mathrm{C}$, and stored at $4^{\circ} \mathrm{C}$ in the refrigerator before use. Biofilms are bacteria that were 
incubated before being transferred to 96 -well plates containing $100-\mu \mathrm{L}$ suspension of $E$. faecalis $\left(1 \times\right.$ of $1 \times 10^{8}$ cells $\left./ \mathrm{mL}\right)$ and added to every well plate. Subsequently, $100 \mu \mathrm{L}$ of BHI was added to each well as a growth medium followed by incubation at $37^{\circ} \mathrm{C}$ for $24 \mathrm{~h}$. After incubation, the medium was discarded, and the supernatant washed with $100 \mu \mathrm{L}$ of phosphate-buffered saline (PBS) solution.

The study continued by exposing E. faecalis biofilms to $100 \mu \mathrm{L}$ of xanthorrhizol of different concentrations $(0.5 \%, 0.75 \%, 1 \%, 1.25 \%$, and $1.5 \%$ ). To the positive control well, CHX 2\% (Gluco-Chex) $100 \mu \mathrm{L}$ was added, while $100 \mu \mathrm{L}$ of BHI was added to the negative control well (biofilm without added material tested). In this study, different concentrations of xanthorrhizol solution were also included as blank samples. Well, plates were subsequently incubated for $15 \mathrm{~min}$ at $37^{\circ} \mathrm{C}$ and then washed once with $100 \mu \mathrm{L}$ of BHI solution. Subsequently, 10 $\mu \mathrm{L}$ of MTT solution ( $5-\mathrm{mg} / \mathrm{mL}$ concentration) was added to each well, which was then incubated in the dark for $3 \mathrm{~h}$ at $37^{\circ} \mathrm{C}$. Further, $100 \mu \mathrm{L}$ of acidified isopropanol was added to each well to stop the reaction. Plates were then placed in an orbital shaker for $1 \mathrm{~h}$. In this study, we used the MTT assay for assessing the potential of the material tested to inhibit E. faecalis when the bacterium grew as biofilm. The inhibition effect was determined based on the optical density value (OD) that was read using an ELISA reader at a wavelength of $490 \mathrm{~nm}$. This was converted to eradication percentage.

$$
\begin{aligned}
& \text { Percentageof biofilmeradication }(\%)= \\
& \left(1\left(-\frac{\text { OD sample-ODblank sample }}{\text { ODnegativecontrol-ODblanknegativecontrol }}\right)\right) \times 100 \%
\end{aligned}
$$

The antibacterial test, using the total plate count method, was conducted by making the biofilm on 96-well plate, taking as much 100 -mL suspension of $E$. faecalis $1 \times 10^{8}$ cells $/ \mathrm{mL}$ of BHI broth, followed by anaerobic incubation at $37^{\circ} \mathrm{C}$ for $24 \mathrm{~h}$. This was subsequently treated by adding $100-\mu \mathrm{L}$ xanthorrhizol of various concentrations. For the positive control, $100 \mu \mathrm{L}$ of $2 \% \mathrm{CHX}$ was added to each well. The bottom of the well plates was subsequently scraped and placed into the $200 \mu \mathrm{L}$ of PBS solution. It was vortexed for $20 \mathrm{~s}$, then the 5 -mL suspension was cultured on BHI agar and incubated anaerobically at $37^{\circ} \mathrm{C}$ for $24 \mathrm{~h}$. Colonies formed after incubation were manually counted. The experiment was conducted in duplicate.

Data were collected and statistically analyzed with SPSS program version 24. Statistical analysis was initially performed to test the normality of the data. If the data were normally distributed, parametric tests were conducted by one-way ANOVA, but if the distribution of the data was not normal, the non-parametric KruskalWallis test was used for analysis. $\mathrm{p}<0.05$ was considered statistically significant.

\section{RESULTS AND DISCUSSION}

The present study used a clinical isolate of E. faecalis from non-vital teeth with periapex abnormalities. E. faecalis from clinical isolates persistently grew as biofilm in the root canal, compared with the laboratory strains. This is because the bacterium originated from native tooth root canals with periapex abnormalities, and as such, it was able to survive with more virulence [11]. In this study, CHROMagar media were used to clinically identify isolates of E. faecalis because it was simple and exhibited good sensitivity and specificity.

This study used E. faecalis biofilm for examining the antibacterial effect of xanthorrhizol because, according to Bukhary et al. (2017), E. faecalis is found in the form of biofilms in root canals. As such, bacterial biofilms must be removed during root canal treatment. The evaluation of the antibacterial effect of irrigation fluid on bacterial biofilms is better able to describe the clinical conditions than bacterial culture studies in the form of planktonic. Bacteria in the form of biofilms are more difficult to kill than planktonic bacteria [12].
Xanthorrhizol was chosen because it is a typical phytochemical compound in temulawak (Curcuma xanthorrhiza Roxb.) from fractionation results based on research by Yue et al. (2015) and has the ability as an antibacterial biofilm E. faecalis ATCC 29212 [9]. The purpose of this study was to analyze the antibacterial effect of xanthorrhizol fractionated from Curcuma xanthorrhiza Roxb. on E. faecalis clinical isolate biofilms.

In this study, xanthorrhizol was tested in various concentrations, which were selected based on research by Yue et al. (2015). Xanthorrhizol $1 \%$ was fractionated from temulawak (Curcuma xanthorrhiza Roxb.) and then dissolved with $30 \%$ ethanol, $1 \%$ DMSO, and $100-\mathrm{mg} / \mathrm{mL}$ sodium methyl cocoyl taurate to xanthorrhizol concentrations of $1 \%$, $0.50 \%, 0.25 \%, 1.125 \%, 0.0625 \%$, and $0.03325 \%$, which were proven in alkaline conditions. Xanthorrhizol was more effective against E. faecalis ATCC 29212 biofilms than CHX at concentrations of $0.0625 \%$ and $0.03325 \%$ [9]. However, the study was tested on E. faecalis ATCC 29212 biofilms, and not compared with CHX 2\%. Therefore, in this study, several concentrations of xanthorrhizol were added $(0.5 \%$, $0.75 \%, 1 \%, 1.25 \%$, and $1.5 \%$ ) for finding the optimum concentration of xanthorrhizol that would eradicate E. faecalis biofilms in clinical isolates compared with $\mathrm{CHX} 2 \%$.

CHX 2\% is used as a positive control because CHX is an irrigation material that has been widely used in effective endodontic treatments to kill E. faecalis. According to Ferraz (2007), CHX 2\% in the form of gels and solutions is more effective in eliminating E. faecalis than $\mathrm{NaOCl} 5.25 \%$ [5].

In this study, dimethyl sulfoxide (DMSO) was used as a xanthorrhizol thinner because it does not have antibacterial properties. As such, it would not bias the results of the study $[13,14]$. Biofilm $E$. faecalis was incubated for $24 \mathrm{~h}$. According to Kim et al. (2013), after $24 \mathrm{~h}$ of incubation, E. faecalis biofilm was in the optimal phase of maturation and bacterial biofilms produced extracellular matrices that improved the integrity of the biofilm structures. The bacterium became resistant to antimicrobial molecular substances [15].

In this study, E. faecalis biofilm was exposed to xanthorrhizol of various concentrations and $\mathrm{CHX} 2 \%$, then incubated for $15 \mathrm{~min}$ at $37^{\circ} \mathrm{C}$. By referring to Sena et al. (2006), who examined the antibacterial effects of CHX 2\% solutions on E. faecalis biofilm, it was revealed that CHX 2\% can kill E. faecalis bacteria completely after 15 min [16].

In this study, antibacterial test for E. faecalis clinical isolate biofilms was observed using the MTT assay and total plate count methods. The antibacterial effect of various concentrations of xanthorrhizol solution was compared with that of $2 \% \mathrm{CHX}$ solution.

Table 1 shows the percentage of biofilm eradication using xanthorrhizol solution at different concentrations and 2\% CHX solution against E. faecalis clinical isolate biofilms. Data processing was performed using SPSS software. The data were normally distributed in the normality test $(p>0.05)$. Next is the statistical test, with the one-way ANOVA significance test obtained a $\mathrm{p}=0.001$. Overall, it can thereby be concluded that there were significant differences in the ability of xanthorrhizol to eradicate $E$. faecalis biofilms in the clinical isolates of test groups.

In Table 1, the highest percentage of eradication was observed in biofilm with added xanthorrhizol $1 \%$ (98.18\%), followed by xanthorrhizol $1.25 \%$ (97.67\%), xanthorrhizol $0.75 \% \quad(97.46 \%)$, xanthorrhizol $1.5 \%(97.23 \%)$, and the lowest xanthorrhizol $0.5 \%$ (97.01\%). Thus, by increasing the concentration of xanthorrhizol, did not result in increasing the percentage of eradication. The optimal xanthorrhizol concentration for eradicating the E. faecalis biofilm of clinical isolates was xanthorrhizol $1 \%$. A post-hoc test was conducted to find out which groups had differences.

Table 2 shows a significant difference between the percentage of E. faecalis biofilm eradication of the xanthorrhizol $1 \%$ with 
Table 1: Mean \pm SD and significance value ( $\mathrm{p}$ value) of $2 \% \mathrm{CHX}$ and various concentrations of XNT solution in eradicating Enterococcus faecalis clinical isolate biofilms

\begin{tabular}{lllll}
\hline Groups & $\mathbf{n}$ & Percentage of biofilm eradication (\%) Mean \pm S.D & 95\% CI & p value \\
\cline { 3 - 5 } & & & Lower bound & Upper bound \\
\hline $0.5 \%$ XNT & 4 & $97.01(0.17)$ & 96.75 & 97.28 \\
$0.75 \%$ XNT & 4 & $97.46(0.26)$ & 97.04 & 97.58 \\
$1 \%$ XNT & 4 & $98.18(0.42)$ & 96.90 & 98.06 \\
$1.25 \%$ XNT & 4 & $97.67(0.48)$ & 96.92 & 97.54 \\
$1.5 \%$ XNT & 4 & $97.23(0.19)$ & 98.02 & 99.04 \\
$2 \%$ CHX & 4 & $98.53(0.32)$ & & \\
\hline
\end{tabular}

One-Way ANOVA Test: *Value of significance based on p<0.05. CHX: Chlorhexidine, XNT: Xanthorrhizol

Table 2: Significance value ( $\mathrm{p}$ value) of difference in ability of $2 \%$ CHX and various concentrations of XNT solution in inhibiting Enterococcus faecalis clinical isolates biofilm

\begin{tabular}{|c|c|c|c|c|c|c|}
\hline Materials testing & $0.5 \%$ XNT & $0.75 \%$ XNT & $1 \% \mathrm{XNT}$ & $1.25 \% \mathrm{XNT}$ & $1.5 \%$ XNT & CHX $2 \%$ \\
\hline $0.5 \%$ XNT & & 1.000 & $0.001 *$ & 0.146 & 1.000 & $0.000^{*}$ \\
\hline $0.75 \%$ XNT & & & $0.012^{*}$ & 1.000 & 1.000 & $0.000^{*}$ \\
\hline $1 \% \mathrm{XNT}$ & & & & 0.532 & $0.008^{*}$ & 1.000 \\
\hline $1.25 \% \mathrm{XNT}$ & & & & & 1.000 & $0.018^{*}$ \\
\hline $1.5 \%$ XNT & & & & & & $0.000^{*}$ \\
\hline $2 \%$ CHX & & & & & & \\
\hline
\end{tabular}

Bonferroni post-hoc test, *Value of significance based on p<0.05. CHX: Chlorhexidine, XNT: Xanthorrhizol

xanthorrhizol $0.5 \%, 0.75 \%, 1.25 \%$, and $1.5 \%$. However, no significant differences were noted between xanthorrhizol 1\% and CHX $2 \%$. Therefore, it can be concluded that there were no significant differences between the antibacterial ability of the xanthorrhizol 1\% group and that of the CHX $2 \%$. In contrast, there were significant differences between the antibacterial ability of the CHX $2 \%$ group and that of the xanthorrhizol $0.5 \%, 0.75 \%, 1.25 \%$, and $1.5 \%$ groups. Based on these statistics, the antibacterial ability of xanthorrhizol $1 \%$ in eradicating E. faecalis biofilms was equivalent to that of the control (CHX 2\%).

In this study, we used the MTT assay for analyzing the potential of the materials tested to inhibit E. faecalis when the bacterium grew as a biofilm. The inhibition effect was determined on the basis of the OD that was read using an ELISA reader with a wavelength of $490 \mathrm{~nm}$. The value obtained was converted to an eradication percentage [17]. Table 1 shows that xanthorrhizol concentrations of $0.5 \%, 0.75 \%, 1 \%$, $1.25 \%$, and $1.5 \%$ all have antibacterial effects on E. faecalis bacterial clinical isolates, but the optimum concentration to kill the bacterium is xanthorrhizol $1 \%$. Table 2 shows a significant difference in the percentage of eradication of E. faecalis biofilms after the bacterium was exposed to xanthorrhizol 1\%. By comparing xanthorrhizol $0.5 \%$, $0.75 \%$, and $1.5 \%$, we found a significant reducing effect with $p<0.05$. In contrast, the effect of xanthorrhizol $1 \%$ was not significantly different when compared with xanthorrhizol 1.25\% ( $p>0.05)$. It can, therefore, be concluded that a high concentration of xanthorrhizol did not have an optimal effect on inhibiting $E$. faecalis biofilm in vitro.

Results from the MTT assay showed that the effectiveness of xanthorrhizol increased as the concentration increased. According to Maira (2017), an increase in the eradication ability of temulawak is directly proportional to an increase in the concentration of Curcuma extract. This is because biofilms have complex structures with an increased extracellular matrix, and a higher concentration of temulawak extract is required to penetrate the biofilm [18]. While at concentrations of $1.25 \%$ and $1.5 \%$, there was a decrease in eradication ability. According to Lestari (2016), a high OD was assumed to occur because of the remnants of concentrated temulawak ethanol extract attached to the well wall. This affects the reduction of the MTT solution [19]. In this study, the concentrations of $1.25 \%$ and $1.5 \%$ decreased the percentage of eradication of the MTT assay results associated with the increase in the concentration of xanthorrhizol. More remnants were attached to the well wall, and this can affect the reduction of the MTT assay results.
Table 3: Mean $\pm S D$ and significance value ( $p$ value) of total colony growth after exposure of $2 \%$ CHX and various concentrations of XNT solutions against Enterococcus faecalis clinical isolates biofilms

\begin{tabular}{llllll}
\hline Groups & $\mathbf{n}$ & $\begin{array}{l}\text { Total colony } \\
\text { Mean } \pm \text { S.D }\end{array}$ & \multicolumn{2}{l}{$\mathbf{9 5 \% \text { CI }}$} & p value \\
\cline { 4 - 5 } & & & $\begin{array}{l}\text { Lower } \\
\text { bound }\end{array}$ & $\begin{array}{c}\text { Upper } \\
\text { bound }\end{array}$ & \\
\hline $0.5 \%$ XNT & 4 & $63.50(11.03)$ & 45.95 & 81.05 & $0.001^{*}$ \\
$0.75 \%$ XNT & 4 & $50.25(8.99)$ & 35.94 & 64.56 & \\
$1 \%$ XNT & 4 & $22.00(10.13)$ & 5.87 & 38.12 & \\
$1.25 \%$ XNT & 4 & $60.50(16.01)$ & 35.02 & 85.97 & \\
$1.5 \%$ XNT & 4 & $82.25(11.02)$ & 64.70 & 99.79 & \\
$2 \%$ CHX & 4 & $11.50(2.38)$ & 7.71 & 15.28 & \\
\hline
\end{tabular}

One-Way ANOVA Test: *Value of significance based on $\mathrm{p}<0.05$.

CHX: Chlorhexidine, XNT: Xanthorrhizol

Table 3 shows the results of antibacterial tests using the total plate count method. It can be concluded that overall, there were significant differences in the results of the xanthorrhizol colonization test against E. faecalis biofilms in the clinical isolates of test groups.

Table 3 shows that xanthorrhizol 0.5\%, 0.75\%, 1\%, 1.25\%, and 1.5\% have antibacterial abilities. The highest isolates of E. faecalis colonies were found in the xanthorrhizol 1.5\% group, with an average value of $82.25 \mathrm{CFU} / \mathrm{mL}$ and the lowest was the xanthorrhizol 1\% group, with a value of $22.00 \mathrm{CFU} / \mathrm{mL}$. A post-hoc analysis was conducted to find out which groups have differences.

Table 4 shows a significant difference in the total colony growth between the $1 \%$ xanthorrhizol group and almost all groups of the test material, except the $2 \%$ CHX group. The significance value of the $1 \%$ xanthorrhizol post-hoc test with $2 \%$ CHX was $\mathrm{p}=1000$ ( $\mathrm{p} \leq 0.05)$. It can be statistically concluded that the antibacterial ability of the $1 \%$ xanthorrhizol on E. faecalis clinical isolate biofilms is equivalent to that of CHX 2\%. Therefore, antibacterial tests using both the MTT assay and total plate count showed similar results in this study.

Tables 1 and 3 reveal that the results of the E. faecalis biofilm eradication test with the MTT assay, and the results of the total plate count on xanthorrhizol 1\%, showed optimal concentrations among other 
Table 4: Significance value ( $\mathrm{p}$ value) of total colony growth after exposure of $2 \%$ CHX and various concentrations of XNT solutions against Enterococcus faecalis clinical isolates biofilms

\begin{tabular}{|c|c|c|c|c|c|c|}
\hline Material testing & $0.5 \%$ XNT & $0.75 \%$ XNT & $1 \% \mathrm{XNT}$ & $1.25 \%$ XNT & $1.5 \% \mathrm{XNT}$ & CHX $2 \%$ \\
\hline $0.5 \%$ XNT & & 1.000 & $0.001^{*}$ & 1.000 & 0.353 & $0.000^{*}$ \\
\hline $0.75 \%$ XNT & & & $0.023^{*}$ & 1.000 & $0.008^{*}$ & $0.001^{*}$ \\
\hline $1 \% \mathrm{XNT}$ & & & & $0.001^{*}$ & $0.000 *$ & 1.000 \\
\hline $1.25 \% \mathrm{XNT}$ & & & & & 0.153 & $0.000 *$ \\
\hline $1.5 \% \mathrm{XNT}$ & & & & & & $0.000^{*}$ \\
\hline $2 \% \mathrm{XNT}$ & & & & & & \\
\hline
\end{tabular}

*Post-hoc Bonferroni Test: *Value of significance based on p<0.05. CHX: Chlor-hexidine, XNT: Xanthorrhizol

xanthorrhizol groups, with an average eradication value of $98.18 \%$ and a colony count value of $22.00 \mathrm{CFU} / \mathrm{mL}$. As noted in Table 4, there is a significant difference between the E. faecalis biofilm colony count value of $1 \%$ in the xanthorrhizol group, with nearly all groups of test material, except CHX $2 \%$. Thus, the significance value of xanthorrhizol $1 \%$ and CHX 2\% based on Tables 2 and 4 had no significant differences; therefore, it can be concluded that the antibacterial effect of xanthorrhizol $1 \%$ on E. faecalis biofilms clinical isolates was equivalent to that of $\mathrm{CHX} 2 \%$.

The antibacterial mechanism of xanthorrhizol is determined by the substances that comprise xanthorrhizol, which are chains of phenols and hydrocarbons. Phenol compounds that contain hydroxyl $(-\mathrm{OH})$ functional groups interact with bacterial cells through an adsorption process involving hydrogen bonds and can change the permeability of cell membranes. High levels of phenol penetration into cells can cause protein coagulation and lysis on cell membranes. The formation of hydrogen bonds between hydroxyl groups in phenol compounds with cell membrane proteins causes disruption to the permeability of the membrane. As such, the essential cell components exit the cell and cause bacterial death [20].

\section{CONCLUSION}

Xanthorrhizol can inhibit E. faecalis biofilms, with xanthorrhizol $1 \%$ being the optimal concentration. In addition, the effect of herbal ingredients against $E$. faecalis biofilm was comparable with that shown by CHX $2 \%$.

\section{ACKNOWLEDGMENT}

This study was supported by the Directorate of Research and Community Engagement of Universitas Indonesia. The publication of this manuscript was supported by Universitas Indonesia.

\section{CONFLICTS OF INTEREST}

There are no conflicts of interest to declare.

\section{REFERENCES}

1. Siqueira F Jr., Rocas I. Causes of endodontic treatment failure. In: Treatment of Endodontic Infections. Berlin: Quintessence Publishing; 2011. p. 139-57.

2. Siqueira FS Jr., Rôças IN. Polymerase chain reaction based analysis of microorganisms associated with failed endodontic treatment. Oral Surg Oral Med Oral Pathol 2004;97:85-94.
3. Arias-moliz T, Marı C, Espigares-garc1 M. Enterococcus faecalis biofilms eradication by root canal irrigants. J Endod 2009;35:711-14.

4. Fisher K, Phillips C. The ecology, epidemiology and virulence of Enterococcus. Microbiology 2018;155:1749-57.

5. Gomes BP, Zaia AA, Souza-filho FJ. Comparative study of the antimicrobial efficacy of chlorhexidine gel, chlorhexidine solution and sodium hypochlorite as endodontic irrigants. Braz Dent J 2007;18:294-98.

6. Faria G, Cardoso CR, Larson RE, Silva JS, Rossi MA. Chlorhexidineinduced apoptosis or necrosis in L929 fi broblasts: A role for endoplasmic reticulum stress. Toxicol Appl Pharmacol 2009;234:256-65.

7. Kandaswamy D, Venkateshbabu N. Root canal irrigants. J Conserv Dent 2010;13:256-64.

8. Penelitian A, Wahyuni WT, Rafi M. Metode ekstraksi dan pemisahan optimum untuk isolasi xantorizol dari temulawak (Curcuma xanthorrhiza). J Jamu Indones 2017;2:43-50.

9. Yue W. The antibacterial effect of xanthorrhizol as an endodontic irrigant on Enterococcus faecalis. Yonsei Univ 2016;1:206-16.

10. Prod JN, Resour P. In vivo toxicological investigations of standardized ethanolic extract of Curcuma xanthorrhiza Roxb. rhizome. J Nat Prod Plant Resour 2013;3:67-73.

11. Sandini A. Daya Anti Bakteri Laser Dioda Terhadap Biofilm Enterococcus faecalis Dari Isolat Klinis [Thesis]. Jakarta: Faculty of Dentistry, Universitas Indonesia. 2016.

12. Bukhary S. Antibacterial efficacy of octenisept, alexidine, chlorhexidine and sodium hypochlorite against Enterococcus faecalis biofilm. J Endod 2017;43:643-7.

13. Irianti $\mathrm{T}$. Uji aktivitas penangkapan radikal dan deteksi senyawa ekstrak etanolik terpurifikasi batang brotowali. J Bahan Alam Indones 2012;8:172-80.

14. Yasui S. Tekonologi Pengolahan Dan Pemanfaatan Produk Ekstraktif Rempah. Indonesia: IPB Press; 2013.

15. Kim H, Chang SW, Baek S, Han SH, Lee Y, Zhu Q. Antimicrobial effect of alexidine and chlorhexidine against Enterococcus faecalis infection. Int J Oral Sci 2013;5:26-31.

16. Sena NT, Gomes BP, Vianna ME, Berber VB, Zaia AA, Ferraz CC. In vitro antimicrobial activity of sodium hypochlorite and chlorhexidine against selected single-species biofilms. Int Endod J 2006;39:878-85.

17. Van M, Kaspers G. Cell sensitivity assays: The MTT assay. Methods Mol Biol 2011;731:237-45.

18. Maira U. Efek in vitro Ekstrak Etanol Temulawak (Curcuma xanthorrhiza Roxb.) Dalam Menghambat Biofilm Candida Albicans Fase Maturasi [Thesis]. Jakarta: Faculty of Dentistry, Universitas Indonesia; 2017.

19. Lestari A. Potensi Ekstrak Etanol Temulawak (Curcuma xanthorrhiza Roxb.) Dalam Mengeradikasi Biofilm Candida albicans Isolat Klinis [Thesis]. Jakarta: Faculty of Dentistry, Universitas Indonesia; 2016.

20. Rukayadi Y, Hwang J. In vitro activity of xanthorrhizol isolated from the rhizome of Javanese turmeric (Curcuma xanthorrhiza Roxb.) against Candida albicans Bio films. Phyther Res 2012;27:1061-6. 